\title{
Forests and climate change adaptation policies in Cameroon
}

\author{
Mekou Youssoufa Bele • Olufunso Somorin • \\ Denis Jean Sonwa $\cdot$ Johnson Ndi Nkem • \\ Bruno Locatelli
}

Received: 3 June 2010 / Accepted: 26 August 2010 /

Published online: 15 September 2010

(C) The Author(s) 2010. This article is published with open access at Springerlink.com

\begin{abstract}
Nowadays, adaptation has become a key focus of the scientific and policy-making communities and is a major area of discussion in the multilateral climate change process. As climate change is projected to hit the poorest the hardest, it is especially important for developing countries to pay particular attention to the management of natural resources and agricultural activities. In most of these countries such as Cameroon, forest can play important role in achieving broader climate change adaptation goals. However, forest generally receives very little attention in national development programme and strategies such as policy dialogues on climate change and poverty reduction strategies. Using a qualitative approach to data collection through content analysis of relevant Cameroon policy documents, the integration of climate change adaptation was explored and the level of attention given to forests for adaptation analysed. Results indicate that, with the exception of the First National Communication to UNFCCC that focused mostly on mitigation and related issues, current policy documents in Cameroon are void of tangible reference to climate change, and hence failing in drawing the relevance of forest in
\end{abstract}

M. Y. Bele $(\bowtie) \cdot$ O. Somorin $\cdot$ D. J. Sonwa

Center for International Forestry Research (CIFOR), P.O. Box 2008, Yaoundé, Cameroon e-mail: b.youssoufa@cgiar.org

D. J. Sonwa

e-mail: d.sonwa@cgiar.org

O. Somorin

Forest and Nature Conservation Policy Wageningen University, P.O. Box 6708 PB, Wageningen, the Netherlands

e-mail: o.somorin@cgiar.org

e-mail: olufunso.somorin@wur.nl

\section{J. N. Nkem}

United Nations Development Programme (UNDP), United Nations Office in Nairobi Gigiri, Block U 308, P.O. Box 30552-00100, Nairobi, Kenya

e-mail: johnson.nkem@undp.org

B. Locatelli

CIRAD UPR Forest Resources, P.O. Box 34398, Montpellier, France

e-mail: bruno.locatelli@cirad.fr

B. Locatelli

Center for International Forestry Research (CIFOR), P.O. Box 16000, Bogor, Indonesia 
sheltering populations from the many projected impacts of climate change. Policies related to forest rely on a generalized concept of sustainable forest management and do not identify the specific changes that need to be incorporated into management strategies and policies towards achieving adaptation. The strategies and recommendations made in those documents only serve to improve understanding of Cameroon natural resources and add resilience to the natural systems in coping with anthropogenic stresses. The paper draws attention to the need to address the constraints of lack of awareness and poor flow of information on the potentials of forests for climate change adaptation. It highlights the need for integrating forest for adaptation into national development programmes and strategies, and recommends a review of the existing environmental legislations and their implications on poverty reduction strategy and adaptation to climate change.

Keywords Climate change $\cdot$ Forests $\cdot$ Adaptation $\cdot$ National policies $\cdot$ Cameroon

\section{Introduction}

While there is uncertainty in the projections with regard to the exact magnitude, rate, and regional patterns of climate change, it is widely agreed that its consequences will change the fate of many generations to come and particularly impact on the poor especially in developing countries if no appropriate measures are taken (IPCC 2007). The adverse effects of climate impacts to which these countries are exposed are already being felt and exerting considerable stress on important sectors for national development such as agriculture and exploitation of natural resources (IPCC 2001; Huq et al. 2003; AIACC 2004; Hassan et al. 2005; Reid et al. 2005; UNFCCC 2007a, b; UNDP 2007; FAO 2008; UNFCCC 2009). This in fact poses a serious threat to national development and poverty reduction (Ogunseitan 2003; World Bank 2004; MEA 2005; Stern et al. 2006; Nkem et al. 2007). Like all over Africa, Cameroon climate has been highly variable throughout the last several decades, often with very high amplitudes (Molua and Lambi 2007; IPCC 2007; IUFRO 2010). In addition to climatic factors which already limit freshwater availability and crop yields in large areas (Hassan 2006; Molua 2008), the situation in Cameroon is aggravated by land degradation, high population growth, poor economic growth, and large social problems, spread of diseases and a general decay of the ecosystem (Annecke 2002; Dixon et al. 2003, Innes and Hickey 2006, Nkem et al. 2007, Asangwe 2002, 2006). These processes are largely interdependent and driven to a high proportion by climate change. To break this disastrous spiral of ever decaying social, economic, and natural conditions, unprecedented efforts are needed based on insights in natural, social, economic, political, and health sciences. The support of decision making processes based on a thorough understanding of all related processes is mandatory to overcome the pressing problem.

\subsection{Why Cameroon forests matter}

\subsubsection{Extent of forest cover and resources}

Cameroon is endowed with abundant natural resources, especially with a large expanse of dense tropical rainforests, predominantly in the southern part. Cameroon forest covers approximately 23 million hectares representing $47 \%$ of the total land area (MINFOF and FAO 2005). In addition, there is 15 million hectares of wooded land in the more arid central and northern parts of the country. In the late 1990s, productive forests comprised about 17 million hectares, representing $78 \%$ of the total forest area in exclusion of protected forest areas (Fig. 1). In fact, 


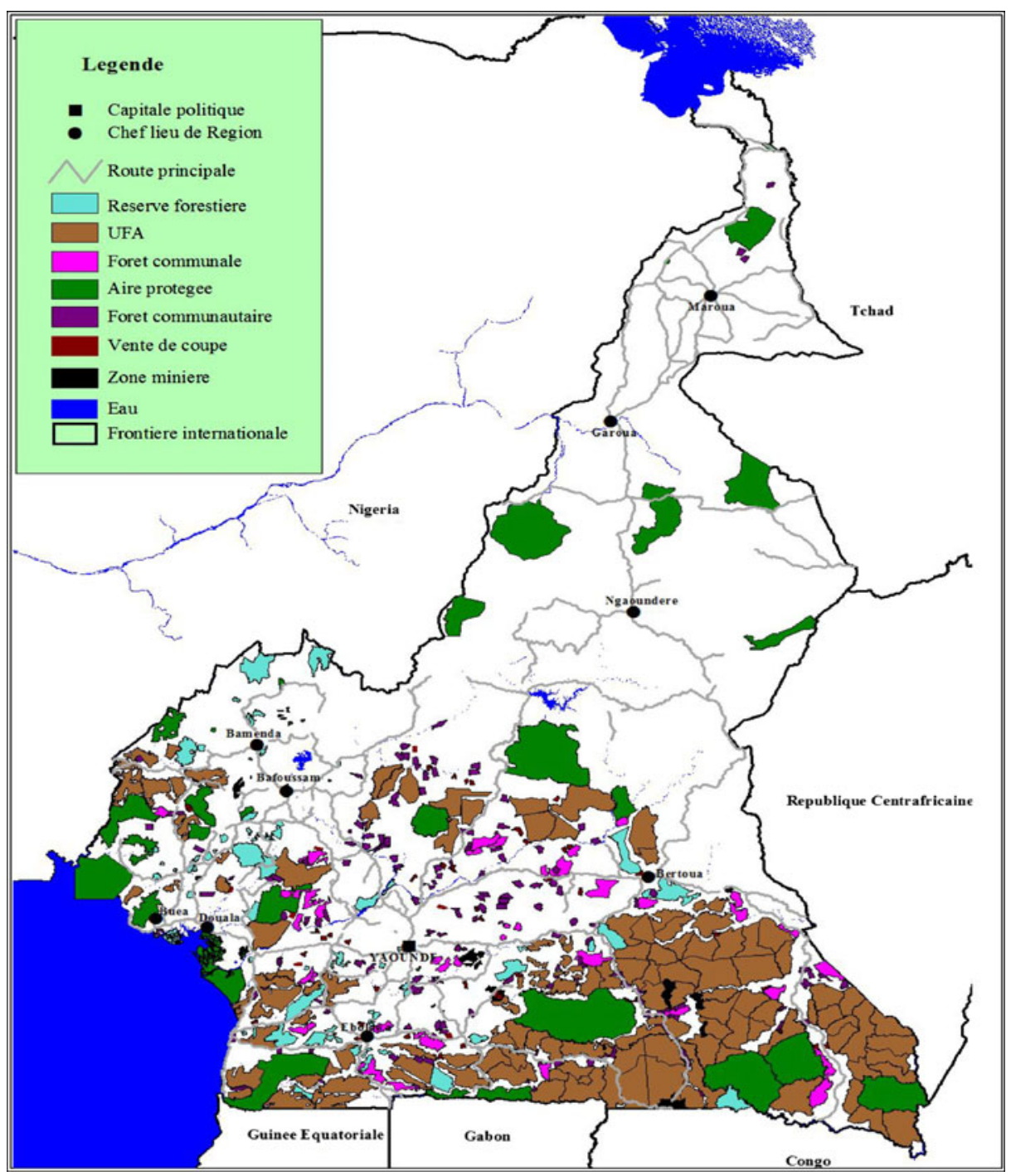

Fig. 1 Map of Cameroon showing distribution of forest (Global Forest Watch 2003)

Cameroon harbours some 8260 plant species (of which 156 are endemic) and around 2000 animal species, which make it to occupy the 5th position in Africa as far as biodiversity is concerned (Essam 2001; NBSAP 2002; GFW 2003).

\subsubsection{Social and economic importance}

In Cameroon, forest ecosystem goods and services provide security portfolios for over $80 \%$ of the local populations and thus, highly crucial for poverty reduction and significantly contributes to national development. As a source of bush meat which constitutes an important source of food for many inhabitants of rural areas and the source of income for many hunters, it is estimated that 78,000 metric tons of bush meat is harvested annually in 
Cameroon forests (Nasi et al. 2008; Wright and Priston 2010). Cameroon forests are used as economic resources to produce subsistence and industrial forest products (Hassan et al. 2005; Reid et al. 2005; CBFP 2006, 2008; Hoare 2007). The economic importance of the forestry sector as recognized by the Government of Cameroon is emphasized in a Policy Framework Paper (1994 Forestry Law), which clearly states that: 'The forests of Cameroon represent one of the country's greatest riches and that the government expects this sector to contribute to growth and macroeconomic balance'. In 2005, fiscal revenues from forestry sector were US\$79,524,912 (MINFOF 2008). Total penalties collected between 2001 and 2004 were about US\$1,788,734 and lot of outstanding sums as penalties not yet collected. Overall, national stock of commercial timber is estimated at 310 million cubic meters representing a standing value of about US\$70 billion) (Essama-Nssah and Gockowski 2000). Cameroon ranks among the world's top five tropical log exporters (GFW 2003). Its timber production reached 4.7 million cubic meters representing 2.5 million in the informal sector and 2.2 million in the commercial sector (Cerutti and Tacconi 2008). Currently, the forestry sector is the third-largest source of export revenue in Cameroon's economy after petroleum, representing $16 \%$ of national export earnings in 2003 (with a value of approximately US\$ 380 million), and about 6\% of GDP (CBFP 2006). In 2006, forest sector employed 163,000 people, of which 13,000 were employed in the forest industry (MINFOF 2008). Other wood-based export products are sawnwood, with an estimated yearly export production of 540,000 cubic meters. According to FAO (2003), traditional fuels, including firewood and charcoal, account for roughly $80 \%$ of all energy consumption in Cameroon.

\subsubsection{Environmental importance}

As part of the Congo Basin forests that constitute the second largest contiguous rainforest in the world, Cameroon forests actively contribute to the world's environmental stability. They perform multiple roles, such as preventing soil degradation and erosion, protecting watersheds or stabilizing mountainous areas. They limit the greenhouse effect contributing to global warming, by absorbing $\mathrm{CO} 2$ (the main greenhouse gas). They are home to a large number of species, therefore acting as a stronghold to safeguard biodiversity (CBFP 2006 \& 2008). They also serve as a living habitat for many indigenous and non-indigenous (CBFP 2006, 2008). In addition, opportunities from international policy on Reduced Emissions from Deforestation and Forest Degradation (REDD) to mitigate climate change through maintenance and restoration of forest carbon sinks, also have the potential to contribute to other goals (Brown et al. 2010). In particular, forest conservation under REDD could contribute to the maintenance of biodiversity as well as ecosystem services in forested areas (Hare and Macey 2008; Streck et al. 2008; Thompson et al. 2009). Conservation of forests would also reduce the vulnerability of local forest-dependent communities to climate change and enable them to adapt (Locatelli et al. 2008). While still hotly debated, many feel that a 'propoor' REDD may represent a strategy for economic development and poverty reduction in developing countries (Luttrell et al. 2007; Richards and Jenkins 2007; Bellasse and Gitz 2008; Brown et al. 2008). Beyond the potential benefits from such a policy, there are many concerns that have been raised regarding not only the challenges to implementation, but also their potential effect on the livelihoods of forest-dependent communities (Izac 1997; Pagiola et al. 2004; Angelsen 2008; Fry 2008; Humphreys 2008; RRI 2008; Skutsch and Trines 2008; Somorin 2008; Ajayi et al. 2009; Brown et al. 2010).

However, the role of forests is not fully captured in the national development planning processes especially in their roles for climate change and poverty reduction strategies. The 
challenge therefore is to increase both public and policy awareness of the role of forests in climate change response and reducing poverty, and to develop livelihood adaptation strategies on a framework of forests goods and services.

\section{About this paper}

This paper explores how climate change adaptation is integrated in the Cameroon major policy documents such as, the Forest-Environment Sector Programme (FESP), the Poverty Reduction Strategy Papers (PRSPs), and the first National Communication to UNFCCC (NC1). To further explore this integration, the paper analyses the level of attention given to forests for adaptation to climate change in the First National Communication to UNFCCC. First, the literature on risks and vulnerability to climate variability and change in Cameroon with focus on impacts on the forest ecosystem is reviewed. Then, using information from research on the vulnerability of forest ecosystems and forest users, we highlight the opportunities for adaptation in Cameroon in the face of climate change. The research methods are further described and the results are discussed with focus on: Cameroon strategy on environmental protection, efforts towards UNFCCC implementation and the analysis of the level of attention given to forest for adaptation in Cameroon in the First National Communication to UNFCCC. The paper ends with a discussion of the challenge of addressing climate change and adaptation in particular in Cameroon and makes suggestions for longer-term adaptation processes to include more integrated programming that links with national development processes.

\section{Climate risks \& vulnerability in Cameroon}

The analysis of climate change impacts ${ }^{1}$ in Cameroon reveals that Cameroon has been impacted in almost all the sectors of development (UNEP 2000 and MINEF 2001). Already the major cause of sickness and death in Cameroon, malaria is reported to be increasing, possibly the consequence of rising temperatures. Predictions for climate change in Cameroon also focus on the reduced volume and predictability of rainfall. Statistics show that rainfall has already decreased by over 2\% per decade since 1960 (Molua and Lambi 2007). Crop yields have been poor; in particular the cash crop has been affected by unsteady rains. The low lying coastal region will be at risk from rising sea levels (Asangwe 2006).

The vulnerability of Cameroon to climate change is compounded by the fact that (1) Poverty exacerbates and is exacerbated by the impacts of environmental change: in Cameroon, most of the recent natural disasters are climate, weather and water related (Ayanji 2004; Molua and Lambi 2007; Molua 2008); (2) Livelihoods are highly dependent on climate-sensitive resources: agriculture in Cameroon, of which up to $90 \%$ is rain-fed, accounts for more than $70 \%$ of the country employment and constitutes the third largest source of foreign exchange for the State, after oil and timber exports, and accounts for more than $40 \%$ of gross domestic product (Hassan 2006; Molua and Lambi 2007); (3) Low adaptive capacity: the poorest populations in areas sensitive to climate change like in the Sudano-Sahelian zone and the coastal areas are already struggling to cope with current

\footnotetext{
${ }^{1}$ Definition of terms used in this paper follow the Glossary of terms used by Working Group II (Climate change, Risks, Impacts, Adaptation, and Vulnerability) of the Third Assessment Report of the Intergovernmental Panel on Climate (2001). Report available at; http://www.grida.no/climate/ippc_tar/wg2/689.htm
} 
extreme weather events and climate variability. The greater frequency and severity of climate shocks is repeatedly eroding coping capacity in most of these areas. The most vulnerable sectors of Cameroon society include: energy resources, health, agriculture and food security, and water resources (UNEP 2000; MINEF 2001).

\subsection{Impacts on forests}

The synthesis of vulnerability studies shows that almost all forest landscapes in Cameroon are affected by the phenomena of variability and climate change. The consequences are very much felt since they relate to people living primarily from natural resources. However, in Cameroon, as in many other Sub-Saharan Africa countries, climate change is just an added stress to a range of other pressures, some of which are currently more pressing than climate change. Pressures such as forest fragmentation, reduction in habitat and the resulting adverse effects on wildlife species are already proving difficult to manage. Inappropriate land use practices have led to increased deforestation and forest degradation, soil erosion, flooding of low lying areas and the destruction of watersheds. It is very likely that even more modest losses in biodiversity would cause consequential changes in ecosystem goods and services (Arnell 2004; IPCC 2007; Dai et al. 2009). However, available information is insufficient to support with a high level of confidence a quantitative assessment of the ecological, social and economic consequences of recent forest responses to climate change. It is also however clear that measures to reduce non-climatic humaninduced pressures can help reduce the overall vulnerability of forest ecosystems and people.

As the population is expected to increase rapidly in the next few decades, demand for wood energy will be high, especially in urban areas. The consequences for forests will be severe, as rising global energy prices and continuing electricity shortages will further concentrate dependence on fuelwood, charcoal and other biomass. As supplies of wood and other products from forests decline, trees grown outside forests on homesteads and communal lands become more important. However, expanding the roles of individuals and companies in growing, protecting and managing trees requires secure tenure and property rights (RRI 2008).

As part of the Congo Basin Forest, the largest in the world after the Amazon forest, Cameroon is committed to sustainable forest management that made it have solid and sustained support from international development institutions and bilateral partners. However, government commitment to implement the resolutions and enforce existing legislation is in conflict with its reliance on timber (Essama-Nssah and Gockowski 2000). Hopes for the rescue of Cameroon's forests have turned to global climate change negotiations which could result in financial compensation in return from REDD. However, whatever is the outcome of the mathematics of REDD, its success will depend on recognition of the needs of people who live in the forest together with the elimination of the culture of corruption amongst government and business interests.

\section{The need for adaptation}

In Cameroon, development and livelihood systems are still closely linked to environmental services given the miniscule transitional changes from land-based economy in diversification of asset portfolios (Nkem et al. 2010). This complex pattern of dependence on natural resources increases the risks, unpredictability and uncertainties surrounding human livelihood as the natural resource systems remain sensitive to changes to climate (Denton et al. 2000; Beg et al. 2002; Ikeme 2003; Seppälä et al. 2009). For instance, forest resources constitute asset bases 
indispensable for the livelihoods of millions of Cameroonian people that depend on them and the national development of the country (Nkem et al. 2007; Somorin and Braatz 2007). Thus, the vulnerability of the forest ecosystems to climate impacts ultimately creates risks to the livelihoods of forest-dependent communities (Barbier et al. 2009) and to national development and economic activities linked to forests. Invariably, adaptation of both the ecological aspects (the forest ecosystem itself) and the social aspects (the people and their livelihoods, which depend on the forest resources) of the coupled system becomes inevitable (Locatelli et al. 2008). It is still against this backdrop that Stern et al. (2006) believes forests can equally serve as an entry point for adaptation. However, a study commissioned by the United Nations Institute for Training and Research (UNITAR) revealed that many African countries including Cameroon do not take climate change as a key priority in their decisionmaking processes and long-term forest management plans (Denton et al. 2000). In addition, despites its importance, forests are not also fully captured in the national development planning processes especially in their roles for climate change and poverty reduction strategies. Therefore, it is necessary to develop institutional and policy interventions necessary to facilitate the incorporation of climate change into forestry such as practical guidance (Guariguata et al. 2007). Such institutional and policy interventions should increase the role of forests in local and national development and facilitate the development of livelihood adaptation strategies on a framework of forest ecosystems.

\section{Methodology}

Three Cameroon policy documents were used for this paper. Those documents were the Poverty Reduction Strategy Papers (PRSPS), the Forest-Environment Sector Programme (FESP) and the First National Communication to Climate Change (NC1). They were chosen because of the fact that they are major policy documents that address quite comprehensively the key issues of biodiversity conservation, sustainable forest management and land degradation within the poverty reduction agenda and thus indirectly dealing with climate change. Analysis focused on their content and explore how climate change adaptation is integrated in those documents and the level of attention given to forest for adaptation in the First National Communication to UNFCCC. Relevant information was included in an Excel database. This information was supplemented by a review of other relevant policy texts, press releases and government statements.

\section{Global policy processes guiding response actions to climate change}

Global warming has been linked to the large injection of anthropogenic emissions of Greenhouse Gases into the atmosphere, resulting in an imbalance in the world's climate system. In 1988 the United Nations General Assembly recognized the need to manage human activities that were affecting, or had potential to affect, the world's climate patterns. Following international negotiations, world Leaders and Decision-Makers signed the UN Framework Convention on Climate Change (UNFCCC) at the Earth Summit in 1992 in Rio de Janeiro, in a bid to combat the global warming phenomenon (UN 1992). The convention entered into force in March 1994 following ratification by 50 countries and today counts 191 member countries, an almost global membership (UNFCCC 2007c). Since then, this Convention is at the centre of efforts to address climate change on the international stage. Its main objective is to "achieve ... stabilization of greenhouse gas concentrations in the 
atmosphere at a level that would prevent dangerous anthropogenic interference with the climate system. Such a level should be achieved within a time frame sufficient to allow ecosystems to adapt naturally to climate change, to ensure that food production is not threatened, and to enable economic development to proceed in a sustainable manner". As a framework treaty, UNFCCC sets out principles and general commitments which are to adopt national programmes for mitigating climate change; to develop adaptation strategies; and to promote the sustainable management and conservation of greenhouse gas "sinks" (such as forests) (UNFCCC 2006a, b). In addition, the UNFCCC acknowledges the use of forestry activities especially in developing countries to reduce vulnerability and variability of both natural and social system (Robledo and Forner 2005).

\section{Environment legal and policy development in Cameroon}

Until the 1980s, environment was not treated as a uniform issue in Cameroon (GEF 2008). Various ministerial departments were involved in environmental management. Forests were managed by the Ministry of Agriculture while Wildlife and Protected Areas were under the Delegation of Tourism. By then, there was no single governmental body that contained the word 'environment'. Though several concerns related to the environment were integrated in the overall planning efforts, this approach did not result in a homogeneous environmental strategy and legal framework. In the early 1990s, Cameroon engaged in the Tropical Forest Action Plan (TFAP), which highlighted that deep institutional and legal reforms were needed in order to establish a transparent, equitable, and sustainable management system for forest resources (Essama-Nssah and Gockowski 2000).

Early at its launch in 1992, Cameroon signed the UNFCC convention and ratified it in 2004, thereby signifying its readiness to contribute to the reduction of green house gas (GHG) emissions. The UNFCCC provided the basis for concerted international action to mitigate climate change and to adapt to its impacts. Its provisions were far-sighted, innovative and firmly embedded in the concept of sustainable development (UNFCCC 2006a, b). Soon after the Rio Summit therefore, Cameroon developed and adopted a framework law on the environment in 1996. This framework law forms the basis for all environmental policies, including steps already taken towards the reduction of GHG emissions, although many of these have been taken primarily to improve the productivity and competitiveness of the industries concerned (Forestry and Wildlife Law No. 94/01 of 20 January 1994 and its various implementing decrees). According to this framework law, "every person shall have a right to a healthy environment. The protection of the environment shall be the duty of every citizen. The State shall ensure the protection and improvement of the environment'. A series of reforms also took place during that period to address various environmental issues. The main reforms were the creation of a Ministry of Environment and Forests in 1992, the drafting of a zoning plan in 1993, which aimed at setting clear boundaries between production, protection, and other areas and the elaboration of a new forest law (No 94 of 20 January 1994) regulating forests, wildlife and fisheries.

However, with the arrival of the new century, the environmental sector embraced, under the double influence of the Millennium Development Goals and the Poverty Reduction Strategy Paper, the social and economic dimensions of sustainability. Consequently, Cameroon's Strategy Document for the Development of the Rural Sector (DSDSR) elaborates strategies to ensure agricultural and environmental sustainability as instruments to promote food security, increase agricultural production and reduce rural poverty. Based on this guidance, the Forest-Environment Sector Programme (FESP) and the Preliminary 
National Development Plan (PNDP) address quite comprehensively the key issues of biodiversity conservation, sustainable forest management and land degradation within the poverty reduction agenda and thus indirectly dealing with climate change (GEF 2008).

In addition, as climate change is a global issue necessitating global efforts, Cameroon is also highly concerned. As part of the Congo Basin which plays a global role in carbon sequestration and climate regulation, slowing down deforestation in Cameroon is extremely important. In this regard, Cameroon established in its Initial National Communication to the UNFCCC a detailed program for reinforcing national capacity, transfer of appropriate technology and putting in place mechanisms for compensation and substitution and adopted in 2002 a National Energy Action Plan for Poverty Reduction.

\section{Cameroon efforts towards UNFCCC implementation}

In Cameroon, pressure on natural resources including forest resources is overwhelming. As such, overexploitation of these resources and unsustainable management practices is affecting the socio-economic fabric of Cameroon as well as reducing the resilience of the environment and increasing its vulnerability to the adverse effects of climate change. In an attempt to address this, the Cameroon government has developed various sustainable management policies with the realization that such polices will be the most beneficial response strategy to help cope with climate change and other environmental and socio-economic problems. This strategy is in line with the Principles contained in Article 3 of the UNFCCC which refers to the development of policies and measures related to sustainable development, by parties, to protect the climate system against human-induced change, and these should be integrated with national development programmes. In this line, Cameroon's sustainable development policies are articulated in the Poverty Reduction Strategy Paper (PRSP 2003) and the Strategy Document for the Development of the Rural Sector (DSDSR). However, up to date, Cameroon has not specified any criteria for sustainable development. It is being guided by the UN Millennium Goals, the NEPAD objectives, the Strategic Document on the Reduction of Poverty, and the individual policies in the principal sectors of activity. In this context, effective response to climate change in Cameroon calls therefore for an integrated sector response drawing on the foundation of the various environmental legislative articles that currently exist.

\section{Place of climate change in national policy documents in Cameroon}

From the three major policy documents in Cameroon and other relevant policy texts, press releases and government statements, reviewed for this paper, the First National Communication submitted to UNFCCC in 2005 is the only document that deals directly with the issues of climate change though mostly focused on mitigation aspects and related issues. With the exception of this document, all the other Cameroon policy documents reviewed are devoid of any tangible climate change policy.

\subsection{Forest-environment sector programme (FESP)}

Forest-Environment Sector Programme document (FESP) deals intensively with sustainable forest management in all aspects. It contains a series of environmental and fiscal policy and legislative reforms, particularly in the forestry sector that help improve its contribution to rural development and economic growth of Cameroon. However, this document does not contain the 
word "climate change". This can be explained by the absence of climate change in the operational policies in Cameroon. As such, adaptation to climate change has failed to be at the forefront of any government's forest policy agenda. Institutional forest policy arrangements, in particular, forest management agreements between the government and the forest industry that define the dominant tenure arrangement in Cameroon do not contain provisions for climate change impacts and adaptation. However, throughout the FESP document, forest management actions already embody many of the activities required to respond to the effects of climate change on forests (Carret 2000 and Karsenty 2006). Most especially, Cameroon Forestry and Wildlife Law No. 94/01 of 20 January 1994 and its various implementing decrees contain detailed strategies relating to the conservation of Cameroon natural resources and sustainable development. Such strategies include adaptive actions for gene management, forest protection, forest regeneration, silvicultural management, forest operations, non-timber resources, and park and wilderness area management (adaptation of forest and not forest for adaptation). In addition, collaboration and fine-tuning of management requirements by concessionaires, civil society and the public are already yielding results, notably with the issuance of FSC certificates. As such, Cameroon is regarded as the leader amongst the countries of the central Africa sub-region who are queuing up to benefit from its experience as they revise their own legislative texts in favour of participatory management (Fomété and Vermaat 2001; Oyono 2005; Oyono et al. 2007).

However, how the issue of climate change can be vividly part of the forest policy agenda remains a challenge in Cameroon. This is because "an issue such as climate change becomes part of government's agenda only when three relatively independent streams (problem, policy, and the political) converge and are coupled, promoted by a "policy entrepreneurs," and only then do policy decisions occur when policy windows open (budgets, elections, international agreements, etc) (Kingdon 1995) ". This seems not to be the case in Cameroun yet. The government has other immediate priorities than climate change such as poverty reduction, job creation, etc.

\subsection{Poverty reduction strategy papers (PRSPs)}

PRSPs provide a framework for domestic policies and programs, as well as for foreign assistance, with the overall aim of reducing poverty. PRSPs are written by the countries and are comprehensive and result-oriented documents (Bojo et al. 2004). At the national level, PRSPs can act as a key instrument to link poverty and climate change agendas.

In Cameroon, policies to improve national development and combat poverty are enshrined in the 2003 Poverty Strategy Paper (PRSP) carried out with the assistance of the World Bank and other international donors. These policies reflect the Government's ambition to attain most of the Millennium Development Goals such as eradicating extreme poverty, ensuring environmental sustainability, ensuring gender equity and empowerment. The PRSP further best describes the current character of poverty in Cameroon and the government's priorities and strategy for reducing it. As a matter of facts, the adoption of PRSP was a milestone in the process of reforms carried out by the Cameroon Government since October 2000, when the country reached the decision point of the Enhanced Initiative for Heavily Indebted Poor Countries (HIPC). The central objective of these reforms, which the Government is pursuing with determination, is to significantly reduce poverty, with a strong and sustainable economic growth, increased efficiency of public expenditure, more effective targeting of its poverty reduction policies and improvement in overall governance.

With regard to climate change, information from the 2003 PRSP have been related to Cameroon's main climate change document, its First National Communication (NC1) under 
the UNFCCC, published in early 2005. Incidentally, the paper failed to address vividly the issues of climate change. However, if properly reached, the PRSP objectives could significantly contribute indirectly to adaptation to climate change as the vulnerability of social and ecological systems will be significantly reduced. As a matter of fact, on the environmental sector, the PRSP recognizes that poverty is at the heart of environmental problems in Cameroon and that improving management capacity in environmental sector will be needed in order to achieve more sustainable management of natural resources. Improvements in capacity are expected to enhance growth in forestry industry, agriculture, tourism and therefore, enhance livelihoods and contribute to poverty reduction.

\subsection{First national communication to UNFCCC (NC1)}

According to Articles 4 and 12 of the Framework Convention on Climate Change, Parties are required to submit their Communications to the Conference of the Parties (COP). Such communications should include National Greenhouse Gas Inventories and national plans to mitigate climate-change impacts and measures to facilitate adequate adaptation to climate change without a further increase in the emissions of Greenhouse Gases. In this context, the Cameroon $\mathrm{NC} 1$ has been prepared in accordance with guidelines issued following the $2 \mathrm{nd}$ Conference of Parties (COP2) to the treaty. It presents an overview of national circumstances, particularly aspects that relate to climate-change issues, presents a Greenhouse Gas inventory, and analyses mitigation strategies, vulnerability assessment and adaptation assessments and options. An overview of policies and programmes relating to the implementation of the convention is presented, including identified project concepts for further refinement and funding. The Cameroon $\mathrm{NC1}$ addresses the vulnerability of two major zones sensitive to climate change in great details: the Coastal Area and the SudanoSahelian zone. The document also emphasizes the fact that mitigation measures will enable Cameroon to participate in technology-transfer opportunities, especially when it is reasonable to assume that emissions will continue to increase in the future.

Taking 1994 as baseline, the NC1 suggests that Cameroon emission of GHG in the atmosphere is 43 million tonnes equivalent carbon dioxide. The main gases emitted are $\mathrm{CO}_{2}$ (55.9\%), $\mathrm{CH}_{4}(25.3 \%)$ and $\mathrm{N}_{2} \mathrm{O}(18.8 \%)$, with agriculture activities and land use changes accounting for the majority of emissions. The document suggests that, to have a significant reduction in the national emissions of GHG gases in Cameroon, mitigation measures will need to target the release of carbon dioxide from these sectors. For that, three basic major policy options available for the mitigation of greenhouse gases were proposed: (1) development of sinks, such as afforestation and sustainable forest management, to remove greenhouse gases from the atmosphere, (2) reduce energy consumption while maintaining the level of service desired by the user, and (3) increase energy-conversion efficiencies, or replace fossil fuels with renewable energy. However, all these options still remain largely theoretical in Cameroon.

In general, the absence or little recognition of climate change language in major policy documents in Cameroon is important to recognize the low awareness of the implications of climate change into poverty reduction strategies.

\section{Level of attention given to forests for adaptation in the first national communication}

In Cameroon, like in many other developing countries, the discussion on climate change impacts and adaptation is clustered within the National Communications to UNFCCC. These 
communications provide a good example of systematic progression from national level climate change projections, impact assessments, and identification of specific adaptation responses. The impact assessments cover all crucial climate sensitive sectors for the national economy, namely agriculture, forestry, water management and energy (MINEF 2001). Up to date, Cameroon has only produced and submitted the First National Communication to UNFCCC (NC1). However, an examination of the level of attention devoted to the sections pertaining to impacts, mitigation and adaptation in this document shows that Cameroon has focused its activities under the UNFCCC on mitigation and related issues. The limited attention to impacts and adaptation is indicative in part of the primary focus on mitigation, both within international climate negotiations (Najam et al. 2003) and within scientific assessments as well (Kates 1997; Agrawala 2004; Guariguata 2007). Adaptation also frequently occurs within a suite of responses that may be linked to a broad range of societal concerns, many of which fall outside the "climate change only" focus of climate assessments and policy (Gagnon-Lebrun and Agrawala 2006).

Within the Cameroon's NC1, policies related to forest rely on a generalized concept of sustainable forest management and do not identify the specific changes that need to be incorporated into management strategies and policies towards achieving adaptation. The document shows that the Government only focused on the formulation and the adoption of a modern legal and regulatory framework for forest resource management with key elements enshrined in the 1994 Forestry, Wildlife and Fishery Law and its various implementation texts. Therefore, it would be important that the government consolidates a plan of action for better integration of climate change adaptation into national development policy and public investment decisions.

The strategies and recommendations made in the $\mathrm{NC1}$ can only serve to improve understanding of Cameroon natural resources and add resilience to the natural systems in coping with anthropogenic stresses. In this regard, Cameroon's vision on natural resources is that of a country that (1) exploits or rationally utilises her natural biological resources sustainably to meet the development needs and the well-being of her increasing population, (2) preserves its ecosystem balance, and (3) hands down the richness of her biodiversity to future generations (NBSAP 2002).

Within the forestry sector, possible adaptation measures include reforestation of degraded or cleared areas, control and monitoring of timber exploitation, regulation of sand mining, reduction of land-based pollution, and relocation of fishing camps to behind the mangroves (NBSAP 2002).

\section{Factors underscoring poor integration of climate change into national policy}

In Cameroon, although climate change is increasingly perceived as having a high priority, problems such as poverty reduction and job creation remain the Government current top priorities (Brown et al. 2010). Currently, there is no specific programme on climate change adaptation in Cameroon. In addition, though well aware of its eventual impacts on various sectors, climate change and more precisely climate change adaptation is not yet in the agenda of many stakeholders (Brown et al. 2010). Many factors underscore this: poor data on adaptation options; limited awareness of adaptation among stakeholders and the population; low staff capacity for planning, monitoring and evaluation; lack of mechanisms for information sharing and management across sectors; inadequate institutional capacities, and lack of commitment and incentives to enforce Forest Law (Tieguhong and Ndoye 2007; Tieguhong and Betti 2008). 
Therefore, to facilitate adaptation strategies especially in the forest sector, the following actions have been identified: assess risk and vulnerability; enhance the role of sustainable forest management in climate change adaptation; enhance forest and biodiversity management to increase resilience and reduce risk and vulnerability; mainstream climate change into forest management; strengthen a sustainable financing mechanism; support capacity development, and create local employment (Bele et al. 2009)

\section{Conclusion}

Like many other developing countries, Cameroon is already suffering from the impacts of climate variability and change. Although endowed with potentials for the well-being of its people and the State as well as people of the rest of the world, through their climate change mitigation capacity, Cameroon forests are vulnerable to climate change. However, Cameroon's responses so far to the challenges and opportunities of climate change have been slow, inadequate and erratic. As climate change appears to be progressing too quickly for decisions to be delayed pending the outcome of future studies and irrespective of the uncertainties, Cameroon must make climate change mitigation and adaptation decisions now. National policies should integrate climate change. Cameroon should also develop national and local climate change institutional frameworks to strength the coordination, networking and information flows with different levels of governments and local civil society to have better response to poverty eradication and climate change. As a country with clear dependency on climate sensitive sectors such agriculture, forestry, fishery, pastoralism, etc. uncertainties in adaptive capacity in Cameroon are profound. Recognition of the nature of this uncertainty can be an essential starting point for use of information for decision-making in this area. In the forest sector most specifically, Cameroon should develop a sustainable forest management policy that include a climate change focus that has the potential not only to avoid any adverse effects on forest resources and conservation of biodiversity but also to provide opportunities for greater, more sustainable rural development and poverty alleviation through income generation and employment opportunities.

Acknowledgements We would like to thank all those who have provided us with documents and information necessary for this paper. We sincerely thank Nkakene Njoya Zouliatou for her useful comments especially English proof reading on early version of the paper. We are also very grateful to anonymous reviewers whose comments and suggestions have substantially improved the manuscript. Special thanks go to the International Development Research Centre (IDRC), the funding agency of the Congo Basin Forests and Climate Change Adaptation project in Central Africa (CoFCCA) executed by the Center for International Forestry Research (CIFOR).

Open Access This article is distributed under the terms of the Creative Commons Attribution Noncommercial License which permits any noncommercial use, distribution, and reproduction in any medium, provided the original author(s) and source are credited.

\section{References}

Agrawala S (2004) Towards Mainstreaming Climate Change Adaptation in Development Assistance and Planning: Challenges and Opportunities. IDS Bulletin 35(3)

Ajayi OC, Akinnifesi FK, Sileshi G, Chakeredza S, Mgonba S (2009) Integrating food security and environmental quality in southern Africa: Implications for policy. In: Luginaah IN, Yanful EK (eds) Environment and Health in Sub-Saharan Africa: Managing an Emerging Crisis. Springer Publishers, Netherlands

Angelsen A (ed) (2008) Moving ahead with REDD: issues, options and implications. CIFOR, Bogor 
Annecke W (2002) Climate change, energy-related activities and the likely social impacts on women in Africa. Int J Global Environ Issues 2:206-222

Arnell NW (2004) Climate change and global water resources: SRES emissions and socioeconomic scenarios. Global Environmental Change 14:31-52

Asangwe CK (2002) Managing the Dynamics of the Estuarine systems on the Douala lagoon in Cameroon. In: Robin G, Jakeways J (eds) INSTABILITY. Planning and Management. Thomas Telford, London, pp 581-588

Asangwe CK (2006) The Douala coastal lagoon complex, Cameroon: Environmental Issues. In Administering Marine Spaces: International Issues. FIG publication No 36, Copenhagen, Denmark, pp 134-147

Assessments of Impacts and Adaptations to Climate Change (AIACC) (2004) Science in Support of Adaptation to Climate Change. Recommendations for an Adaptation Science Agenda and a Collection of Papers Presented at a Side Event of the 10th Session of the UNFCCC COP, Buenos Aires, Argentina, 7 December 2004. www.aiaccproject.org/whats_new/Science_and_Adaptation.pdf. Accessed 10 July 2010

Ayanji YEN (2004) A Critical Assessment of the Natural Disaster Risk Management Framework in Cameroon. An End-of-Course Case Study Submitted to the Department of City Management and Urban Development of the World Bank Institute in Partial Fulfillment of the Requirements for the Award of a Certificate in Natural Disaster Risk Management

Barbier B, Yacouba H, Karambiri H, Zoromé M (2009) Human vulnerability to climate variability in the Sahel: farmers' adaptation strategies in northern Burkina Faso. Environmental Management 43:790-803

Beg N, Morlot JC, Davidson O, Afrane-Okesse Y, Tyani L, Denton F, Sokona Y, Thomas JP, La Rovere E, Parikh JK, Parikh K, Rahman AA (2002) Linkages between climate change and sustainable development. Climate Policy 2:129-144

Bele MY, Sonwa JD, Nkem J and Nkakene NZ (2009) Adapting Congo basin forest management to climate change Linkages among biodiversity, climate change and forest loss. Poster presented at the World Forestry Congress in 2009. Buenos Aires, 2009

Bellasse V, Gitz V (2008) Reducing Emissions from Deforestation and Degradation in CameroonAssessing costs and benefits. Ecological Economics 68(1-2):336-344

Bojo J, Green K, Kishore S, Pilapitiya S, Reddy R (2004) Environment in poverty reduction strategies and poverty reduction support credits. Working Paper No. 30890. The World Bank, Washington, DC. www. basel.int/industry/wkshop-1206/3.\%20Additional\%20materials/Bojo\%20paper\%20on\%20env\%20in\% 20 Accessed 28 March 2009

Brown D, Seymour F, Peskett L (2008) How do we achieve REDD co-benefits and avoid doing harm? In: Angelsen A (ed) Moving ahead with REDD: issues, options and implications. CIFOR, Bogor, pp 107118

Brown HCP, Nkem JN, Sonwa DJ, Bele Y (2010) Institutional adaptive capacity and climate change response in the Congo Basin forests of Cameroon. Mitig Adapt Strateg Glob Change 15:263-282

Carret J-C (2000) "La Réforme de la Fiscalité Forestière au Cameroun: Débat Politique et Analyse. Economique," Bois et Forêts des Tropiques: 37-51

Cerutti PO, Tacconi L (2008) Forests, illegality, and livelihoods: the case of Cameroon. Society and Natural Resources, 21:845-853 Deposition in Asia. Washington, DC: The World Bank

Congo Basin Forest Partnership (CBFP) (2006) Les forêts du Bassin du Congo. Etat des Forêts 2006, Congo Basin Forests Partnership, Kinshasa, Democratic Republic of Congo

Congo Basin Forest Partnership (CBFP) (2008) Les forêts du Bassin du Congo. Etat des Forêts 2008, Congo Basin Forests Partnership, Kinshasa, Democratic Republic of Congo

Dai A, Qian T, Trenberth KE, Milliman JD (2009) Changes in continental freshwater discharge from 19842004. Journal of Climate 22(10):2773-2792

Denton F, Sokona Y, Thomas JP (2000) Climate change and sustainable development strategies in the making: what should west African countries expect? OECD, ENDA-TM, Dakar, Senegal

Dixon RK, Smith J, Guill S (2003) Life on the edge: vulnerability and adaptation of African ecosystems to global climate change. Mitig Adapt Strat Glob Change 8:93-113

Essam S (2001) Intégration de la biodiversité dans les procédures d'évaluation environnementales : Cas du Cameroun. Etude financée par Komex Clarke Bond Limited

Essama-Nssah \& Gockowski (2000) Forest Sector Development in a Difficult Political Economy; An Evaluation of Cameroon's Forest Development and the World Bank, World Bank Operations Evaluation Department, January 2000, Washington DC

Fomete T, Vermaat J (2001) Community Forestry and Poverty Alleviation in Cameroon. Rural Development Network. Network paper $25 \mathrm{~h} .9 \mathrm{p}$

Food and Agriculture Organization of the United Nations (FAO) (2003) State of the World's Forests

Food and Agriculture Organization of the United Nations (FAO) (2008) Adapting to climate change. Unasylva No. 231/232 Vol. 60 (2009/1-2). FAO, Rome 
Fry I (2008) Reducing emissions from deforestation and forest degradation: opportunities and pitfalls in developing a new legal regime. RECIEL 17:166-182

Gagnon-Lebrun F, Agrawala S (2006) Progress on adaptation to climate change in developed countries an analysis of broad trends. $63 \mathrm{p}$

Global Environment Facility (GEF) (2008) GEF Country Portfolio Evaluation: Cameroon (1992-2007). Global Environment Facility Evaluation Office. $113 \mathrm{p}$

Global Forest Watch (GFW) (2003) Interactive Forestry Atlas of Cameroon: An Overview. Version $1.047 \mathrm{p}$

Guariguata MR, Cornelius JP, Locatelli B, Forner C, Sánchez-Azofeifa GA (2007) Mitigation needs adaptation: Tropical forestry and climate change. Mitig Adapt Strateg Glob Change. doi:10.1007/ s11027-007-9141-2

Hare B, Macey K (2008) Tropical deforestation emission reduction mechanism: a discussion paper, Greenpeace

Hassan R (2006) Climate change and african agriculture. Policy Note prepared based on Molua \& Lambi (2006), Climate, hydrology and water resources in Cameroon, CEEPA Discussion Paper No. 33, CEEPA. University of Pretoria. $8 \mathrm{P}$

Hassan R, Scholes R, Ash N (eds) (2005) Ecosystems and human well-being - volume 1: current state \& trends. Island Press, Washington, DC, $917 \mathrm{p}$

Hoare AL (2007) Clouds on the horizon: the Congo Basin forests and climate change. The Rainforest Foundation, London

Humphreys D (2008) The politics of ‘Avoided Deforestation': historical context and contemporary issues. Int For Rev 10:433-442

Huq S, Rahman A, Konate M, Sokoto Y, Reid H (2003) Mainstreaming adaptation to climate change in least developed countries (LDCs), International Institute for Environment and Development, pp 1-40

Ikeme J (2003) Climate change adaptation deficiencies in developing countries: the case of sub-Saharan Africa. Mitigation and Adaptation Strategies for Global Change 8(1):29-52

Innes JL, Hickey GM (2006) The importance of climate change when considering the role of forests in the alleviation of poverty. International Forestry Review 8:406-416

Intergovernmental Panel for Climate Change (IPCC) (2001) Climate Change 2001: impacts, adaptation, and vulnerability, contribution of working Group II to the third assessment report of the IPCC. Cambridge University Press, Cambridge

Intergovernmental Panel for Climate Change (IPCC) (2007) Climate change 2007: Impacts, Adaptations and Vulnerability. Contribution of Working Group II to the Third Assessment Report of the Intergovernmental Panel on Climate Change [Parry, Martin L., Canziani, Osvaldo F., Palutikof, Jean P., van der Linden, Paul J., and Hanson, Clair E. (eds.)]. Cambridge University Press, Cambridge, United Kingdom, $1000 \mathrm{p}$

International Union of Forestry Research Organization (IUFRO) (2010) Adaptation des forêts africaines au changement climatique: vue régionale des consequences du changement climatique sur les forêts et les populations, et des options pour l'adaptation. http://www.iufro.org/download/file/5515/4624/africanpolicy-brief-fr.pdf (Accessed 14 June 2010)

Izac A-MN (1997) Developing policies for soil carbon management in tropical regions. Geoderma 79:261-276

Karsenty A (2006) L'impact des réformes dans le secteur forestier en Afrique Centrale. In Nasi R., Nguingiri J C, Ezzine de Blas D (eds.). L'Harmattan, pp 25-60

Kates RW (1997) Climate Change 1995 - Impacts, Adaptation, and Mitigation. Environment 39(9):29-33

Kingdon J (1995) Agendas, alternates, and public policies, 2nd edn. Little Brown, Boston

Locatelli B, Markku K, Brockhaus M, Colfer CJP, Murdiyarso D, Santoso H (2008) Facing an uncertain future. How forests and people can adapt to climate change. $100 \mathrm{p}$

Luttrell C, Schreckenberg K, Peskett L (2007) The implications of carbon financing for pro-poor community forestry, Forestry Briefing 14 Forest Policy and Environment Programme. Overseas Development Institute, Forestry Briefings Series, London, pp 1-5

Millenium Ecosystem Assessment (MEA) (2005) Ecosystem and Human Well-Being: Our human planet. Summary for policy makers, Island Press

Ministry of Environment and Forestry (MINEF) (2001) First initial communication to climate change. National report submitted to UNFCCC. $160 \mathrm{P}$

Ministry of Forest and Wildlife of Cameroon (MINFOF) (2008) Programme Sectoriel Forêt-Environnement. Rapport annuel d'activité 2007, une vue globale sur les activités programmées et les principaux résultats atteints au courant de l'année 2007. Observations, limites et recommandations, Février 2008, Cameroun

Ministry of Forest and Wildlife of Cameroon (MINFOF) and Food and Agriculture Organization of the United Nations (FAO) (2005) Evaluation des ressources forestières nationales du Cameroun. Ministère des Forêts et de la Faune (MINFOF) et FAO, Yaounde, Cameroun

Molua E (2008) Turning up the heat on African agriculture: The impact of climate change on Cameroon's agriculture. AfJARE Vol 2 No $1.20 \mathrm{p}$ 
Molua EL, Lambi CM (2007) The Economic Impact of Climate Change on Agriculture in Cameroon. Policy Research Working Paper 4364. The World Bank Development Research Group Sustainable Rural and Urban Development Team. 33 p

Najam A, Huq S, Sokona Y (2003) Climate Negotiations Beyond Kyoto: Developing Countries Concerns and Interests. Climate Policy 3:221-231

Nasi R, Brown D, Wilkie D, Bennett E, Tutin C, van Tol G,Christophersen T (2008) Conservation and use of wildlife based resources: the bushmeat crisis, Technical Series No.33. Secretariat of the Convention on Biological Diversity, Montreal, and Center for International Forestry Research, Bogor

National Biodiversity Strategy Action Programme of Cameroon (NBSAP) (2002) National Biodiversity Strategy and Action Plan. A consultancy report submitted to MINEF. $174 \mathrm{P}$

Nkem J, Santoso H, Murdiyarso D, Brockhaus M, Kanninen M (2007) Using tropical forest ecosystem goods and services for planning climate change adaptation with implications for food security and poverty reduction. Journal of Semi-Arid Tropical Agricultural Research 4(1):1-23

Nkem J, Kalame FB, Idinoba M, Somorin OA, Ndoye O, Awono A (2010) Shaping forest safety nets with markets: Adaptation to climate change under changing roles of tropical forests in Congo Basin. Environmental Science \& Policy

Ogunseitan OA (2003) Framing environmental change in Africa: cross scale institutional constraints on progressing from rhetoric to action against vulnerability. Glob Environ Change 13:101-111

Oyono PR (2005) Profiling local-level outcomes of environmental decentralizations: the case of Cameroon's forests in the Congo Basin. J Environ Dev 14:1-21

Oyono PR, Ribot JC, Assembe S, Logo PB (2007) Improving Decentralized Forest Managementin Cameroon: Options and Opportunities from Ten Years of experience. CIFOR Governance Brief, No.33

Pagiola S, Agostini P, Gobbi J, de Haan C, Ibrahim M, Murgueitio E, Ramírez E, Rosales M, Ruíz J (2004) Paying for biodiversity conservation services in agricultural landscapes. Environment Department Paper No.96, the World Bank, Washington DC, USA

Poverty Reduction Strategy Reduction Paper (PRSP) (2003). Poverty Reduction Strategy Paper for Cameroon. 234 p.

Reid WV, Mooney HA, Cropper A, Capistrano D, Carpenter SR, Chopra K, Dasgupta P, Dietz T, Duraiappah AK, Hassan R, Kasperson R, Leemans R, May RM, Mc-Michael AJ, Pingali P, Samper C, Scholes R, Watson RT, Zakri AH, Shidong Z, Ash NJ, Bennett E, Kumar P, Lee MJ, Raudsepp-Hearne C, Simons H, Thonell J, Zurek MB (2005) Ecosystems and human well-being: synthesis. Island Press, Washington, DC, $155 \mathrm{p}$

Richards M, Jenkins M (2007) Potential and challenges of payments for ecosystem services from tropical forests, Forestry Briefing 16 Forest Policy and Environment Programme. Overseas Development Institute, Forestry Briefing Series, London, p 8

Right and Resoure Initiative (RRI) (2008) Climate Change and Governance in the Forest Sector. An overview of the issues on forests and climate change with specific consideration of sector governance, tenure, and access for local stakeholders. Right and Resource Initiative. Washington DC. $65 \mathrm{p}$

Robledo C, Forner C (2005) Adaptation of forest ecosystems and the forest sector to climate change. Food and Agriculture Organization of the United Nations, Rome

Seppälä R, Buck A, Katila P (eds.) (2009) Adaptation of Forests and People to Climate Change. A Global Assessment Report. IUFRO World Series Volume 22. Helsinki. $224 \mathrm{p}$

Skutsch M, Trines E (2008) Policy Piece - Report from the UNFCCC meeting in Bali. African Journal of Ecology 46:1-2

Somorin OA (2008) Policy instruments for avoided deforestation in international climate change policy: a gaze into post-Kyoto regime. MSc thesis of Forest and Nature Conservation Policy Group, Wageningen University, Netherlands, $97 \mathrm{p}$

Somorin OA, Braatz S (2007) Impacts of climate change on forest-dependent livelihoods of Africa and their Adaptation Strategies. Unpublished FAO Technical Report, $38 \mathrm{p}$

Stern N et al (2006) The Economics of Climate Change

Streck C, Robert OS, Janson-Smith T, Tarasofsky R (eds) (2008) Climate change and forests: emerging policy and market opportunities. Royal Institute of International Affairs, London

Thompson I, Mackey B, McNulty S, Mosseler A (2009) Forest resilience, biodiversity, and climate change. A synthesis of the biodiversity/resilience/stability relationship in forest ecoystems. Secretariat of the Convention on Biological Diversity, Montreal

Tieguhong JC, Betti JL (2008) Forest and protected area management in Cameroon. Tropical Forest Update. Volume 18 , Number 1

Tieguhong JC, Ndoye O (2007) The impact of timber harvesting in forest concessions on the availability of non-wood forest products (NWFP) in the Congo Basin. FAO Forest Harvesting Case Study 23. ISBN 978-92-5-165709-4 Trends, Volume 1. Island Press, New York 
United Nations (1992) United Nations Framework Convention on Climate Change, available at: http:// unfccc.int/resource/docs/convkp/conveng.pdf

United Nations Development Programme (UNDP) (2007) Human development report 2007/2008: fighting climate change: human solidarity in a divided world. UNDP, New York

United Nations for Environmental Programme (UNEP) (2000) Developing Strategies for Climate Change: The UNEP Country Studies on Climate Change Impacts and Adaptations Assessment. Report 2000:2

United Nations Framework Convention for Climate Change (UNFCCC) (2006a) Background paper Impacts, vulnerability and adaptation to climate change in Latin America. UNFCCC Secretariat, Bonn, Germany

United Nations Framework Convention for Climate Change (UNFCCC) (2006b) United Nations Framework Convention on Climate Change: Handbook. UNFCCC Secretariat. Bonn, Germany. http://unfecc.int/ resource/docs/publications/handbook.pdf

United Nations Framework Convention for Climate Change (UNFCCC) (2007a) Bali Action Plan. http:// unfccc.int/files/meetings/cop_13/application/pdf/cp_bali_action.pdf. Accessed 5 May 2009

United Nations Framework Convention for Climate Change (UNFCCC) (2007b) Investment and financial flows to address climate change. UNFCCC, Bonn

United Nations Framework Convention on Climate Change (UNFCCC) (2007c) Vulnerability and adaptation to climate change in small island developing states - Background paper for the expert meeting on adaptation for Small Island developing States. UNFCCC Secretariat, Bonn, Germany

United Nations Framework Convention for Climate Change (UNFCCC) (2009) NAPA Projects Database. $\mathrm{http}: / /$ unfccc.int/cooperation_support/least_developed_countries_portal/napa_project_database/items/ 4583.php .Accessed 12 July 2010

World Bank (2004) Sustaining Forests: a development strategy. World Bank, Washington DC

Wright JH, Priston NEC (2010) Hunting and trapping in Lebialem Division, Cameroon: bushmeat harvesting practices and human reliance. Endangered Species Research 11:1-12 